\title{
Multitrait Pseudomonas spp. Isolated from Monocropped Wheat (Triticum aestivum) Suppress Fusarium Root and Crown Rot
}

\author{
Habib Ullah, Humaira Yasmin, Saqib Mumtaz, Zahra Jabeen, Rabia Naz, Asia Nosheen, and Muhammad Nadeem Hassan ${ }^{\dagger}$ \\ Department of Biosciences, COMSATS University Islamabad, Islamabad, Pakistan \\ Accepted for publication 26 November 2019.
}

\begin{abstract}
Fusarium root and crown rot is the most common disease of wheat, especially wheat grown in arid zones where drought is a common issue. The development of environmentally safe approaches to manage diseases of food crops is important for humans. The monocropping system recruits beneficial bacteria that promote plant growth through nutrient solubilization and pathogen suppression. In this study, a field where wheat was monocropped for 5 successive years under rainfed conditions was identified. A total of 29 bacterial isolates were obtained from the rhizosphere, endosphere, and phyllosphere of wheat at its harvesting stage. The Gramnegative bacteria were less prevalent $(41 \%)$ but the majority $(75 \%)$ exhibited plant growth-promoting traits. The ability of strains to solubilize nutrients (solubilization index $=2.3$ to 4 ), inhibit pathogenic fungi ( 25 to $56 \%$ ), and produce antifungal compounds was highly variable. The
\end{abstract}

ABSTRACT rhizobacteria significantly promoted the growth and disease resistance of wheat varieties such as Pirsbak-2015 and Galaxy-2013 by inducing antioxidant enzyme activity (0.2- to 2.1-fold). The bacterial strains were identified as Ochrobactrum spp., Acinetobacter spp., and Pseudomonas mediterranea by $16 \mathrm{~S} r R N A$ and $r p o D$ sequence analysis. The endophytic bacterium $P$. mediterranea HU-9 exhibited maximum biocontrol efficacy against wheat root and crown rot diseases with a disease score/disease index from 1.8 to 3.1. The monocropping systems of rainfed agriculture are an ideal source of beneficial bacteria to use as bioinoculants for different crops.

Keywords: disease control and pest management, Fusarium root and crown rot, monocropping system, mycology, plant growth-promoting rhizobacteria, wheat (Triticum aestivum L.)
Fusarium root and crown rot is the most common disease of wheat and occurs in most areas of the world (Moya-Elizondo 2013). The disease is caused by numerous Fusarium spp. and results in significant yield losses, especially in dryland wheat growing regions (Shikur Gebremariam et al. 2018; Volova et al. 2018). Changes in rainfall patterns and prolonged droughts as a result of climate change could increase the expansion of this disease and pose major threats to wheat growing countries, especially arid and semiarid zones where drought occurs for long time periods and wheat is monocropped to fulfill dietary requirements (Poole et al. 2013; Wildermuth et al. 1997). Fusarium root and crown rot is usually managed by different approaches such as chemical control, cultural practices, and biological control (Volova et al. 2018). Biological control is advantageous because of its eco-friendly nature.

Plant growth-promoting rhizobacteria (PGPR) have been successfully utilized in controlling wheat root and crown rot (Barnett et al. 2019; Harish et al. 2019; Winter et al. 2019). They are a heterogeneous group of bacteria living in plant roots and contribute to agricultural productivity through multifarious activities such as biofertilization, bioremediation, phytostimulation, and pathogen suppression (Hassan et al. 2010; Rais et al. 2018; Zia et al. 2019). Thus, PGPR are key factors for maintaining soil health and increasing crop yield. The survival of beneficial rhizobacteria in the rhizosphere until crop maturity is essential to exert beneficial traits on certain crops (Coy et al. 2019). Gram-positive bacteria can

†Corresponding author: M. N. Hassan; nadeem_hassan@comsats.edu.pk

Funding: This work was supported by the Higher Education Commission, Pakistan (research grant 20-2991).

*The $\boldsymbol{e}$-Xtra logo stands for "electronic extra" and indicates that one supplementary figure and one supplementary table are published online.

The author(s) declare no conflict of interest.

(c) 2020 The American Phytopathological Society survive for a long period as a result of their spore-forming ability, whereas Gram-negative bacteria must produce multiple secondary metabolites to compete with inhabitants and maintain their population in the rhizosphere (González and Marketon 2003). Moreover, Gram negative bacteria also have the ability to utilize diverse root exudates such as amino acids, carboxylic acids, and sugars (Cordovez et al. 2015; Kloepper et al. 1980).

The accumulation of rhizobacteria during successive monocropping patterns leads to the development of agriculturally productive soil. One example is disease-suppressive soil, in which disease does not persist or persists at very low levels even in the presence of pathogens and favorable conditions for disease development (Cordovez et al. 2015; Penton et al. 2014; Shen et al. 2015). Soil suppressiveness can be categorized as natural suppressiveness and induced suppressiveness (Larkin 2015; Siegel-Hertz et al. 2018). Natural suppressiveness is independent of cropping patterns, whereas induced suppressiveness is dependent on cropping patterns. Monocropping of susceptible crop varieties leads to the development of induced suppressive soils (Liu et al. 2019; Schroth and Hancock 1982). Induced suppressive soils can further be categorized as general and specific suppressive soils. General suppression is the collective competitive activity of total soil microbiota, whereas specific suppression is the antagonistic activity of a specific group of microorganisms against the plant pathogens of a specific crop (Raaijmakers and Mazzola 2016; Schlatter et al. 2017). General suppressiveness is nontransferable, whereas specific suppressiveness is transferable. General suppressive soils generally contain members of genera Bacillus, Burkholderia, Chthonomonas, Pseudomonas, and Serratia (Shen et al. 2015; van Bruggen and Semenov 2000). Monocropping results in the development of specific suppressiveness, which is also termed as disease decline in the plant rhizosphere by recruiting specific groups of microbes through plant root exudates (Andrade et al. 2011; Cha et al. 2016; Dasgupta et al. 2015; Raza et al. 2015; Zhou et al. 2015). Disease-suppressive soils emerge as a major research domain owing to the establishment of organic and sustainable agriculture, minimization of the use of chemical fertilizers, and 
control of plant pathogens with no or little farming efforts (Cha et al. 2016). Studies revealed that monocropping of vanilla in China resulted in a low incidence of Fusarium wilt (Kloepper et al. 1980; Shen et al. 2015; Xiong et al. 2017; Yin et al. 2013). In addition, wheat monocropping led to induced take-all decline against Gaeumannomyces graminis var. tritici (Chng et al. 2015) and almost eliminated Rhizoctonia root rot disease in Australia after successive monocropping for 7 to 9 years (Yin et al. 2013). These facts necessitate that researchers explore the microbes associated with monocultured crops for their beneficial use. This study aimed to isolate rhizobacteria from the rhizosphere/endosphere of the wheat monocropping system in an arid/semiarid agriculture zone and to harness the effective indigenous strains for the biocontrol of wheat root and crown rot caused by Fusarium spp.

\section{MATERIALS AND METHODS}

Field identification and sampling. A wheat field under monocropping system practiced for 5 successive years was identified in Tammah, Islamabad, Pakistan. Wheat plants were sampled at the harvesting stage. Plants with variable height, leaves (color and area), and panicles (size and number of grains) were randomly selected from the different corners of the field. The plants were gently uprooted, enclosed in paper bags, and transported to the Applied Microbiology and Biotechnology Laboratory at COMSATS University Islamabad. The plants were placed at $4^{\circ} \mathrm{C}$ for further processing.

Bacterial isolation. Bacteria were isolated from the rhizosphere and endosphere of representative wheat plants using the serial dilution method (Hassan et al. 2010; Rais et al. 2016; Shakeel et al. 2015). The composite rhizospheric samples were made by gently removing the soil that adhered to different plant roots and mixing them homogenously, whereas composite endospheric samples were made by pooling each part (e.g., roots, stems, leaves, and panicles) of different plants separately. Each endospheric sample was surface sterilized by dipping in $0.1 \%$ mercuric chloride $\left(\mathrm{HgCl}_{2}\right)$ for 1 to $2 \mathrm{~min}$ and washing twice with sterile distilled water. The parts were dried in layers of sterilized filter paper and crushed in a sterilized mortar and pestle. One gram of rhizospheric soil or fully crushed parts was used to make serial dilutions $\left(10^{-1}\right.$ to $\left.10^{-9}\right)$ and each dilution ( $100 \mu \mathrm{l})$ was spread onto Luria Bertani (LB) agar. All procedures were performed in a laminar flow unit to avoid contamination. Moreover, the solutions and sterile materials used in the experiment were also spread on the LB agar as a sterility control. The inoculated LB agar plates were placed at $37^{\circ} \mathrm{C}$ overnight (the temperature prevailing in the field at the time of crop maturity). A single bacterial colony was picked from the LB agar and preserved in $20 \%$ glycerol at $-20^{\circ} \mathrm{C}$.

Differentiation of Gram-negative bacteria and their plant growth-promoting traits. Gram-negative bacteria were screened by Gram staining and grown on Gould S1 medium (Gould et al. 1985). Gram-negative bacteria were grown on LB agar and observed for their colony morphology, including size, shape, margins, elevations, texture, consistency, and opacity. Plant growthpromoting (PGP) traits of Gram-negative bacteria, such as nutrient solubilization (phosphate, potassium, and zinc), fungal antagonism (F. moniliforme, F. oxysporum, Macrophomina phaseolina, and Pyricularia oryzae), and production of antifungal compounds (cellulases, proteases, and siderophores), were detected in vitro.

Nutrient solubilization assay. The ability of the Gramnegative bacteria to solubilize phosphorous, potassium, and zinc was detected on modified Pikovskaya agar (Nautiyal 1999), Aleksandrove agar (Zhang and Kong 2014), and Bunt and Rovira agar (Bunt and Rovira 1955), respectively. The tested strains were grown overnight on LB broth and inoculated by placing a drop of $2 \mu \mathrm{L}$ on the respective agar on the plate. The inoculated agar plates were incubated at $37^{\circ} \mathrm{C}$ for 4 to 7 days. The appearance of a halo zone around a bacterial colony on the respective agar indicated their ability of that bacteria to solubilize the respective nutrient. The nutrient solubilizing index was measured in millimeters and computed using the following formula (Rashid et al. 2004):

$$
\text { Solublizing index }=\frac{\text { Halo zone diameter }+ \text { Colony diameter }}{\text { Colony diameter }}
$$

The experiment was repeated thrice.

Fungal antagonism assay. Phytopathogenic fungi $F$. oxysporum, $P$. oryzae, F. moniliforme, and M. phaseolina were obtained from the Applied Microbiology and Biotechnology Laboratory at COMSATS University. The antagonistic activity of the bacteria was assessed by the dual culture assay (Hassan et al. 2010; Rais et al. 2016). Briefly, a 5-mm mycelium plug of each actively growing fungus was placed at the center of a potato dextrose agar plate and bacterial strains cultured in LB broth overnight were spotted at equal distances from the fungus. Sterile LB without bacteria was used as the control. The plates were placed at 25 to $28^{\circ} \mathrm{C}$ for 7 to 15 days and observed for the inhibition of fungal growth. The percentage of inhibition was calculated as follows (Shakeel et al. 2015): Inhibition $(\%)=[(\mathrm{C}-\mathrm{T}) \times 100) / \mathrm{C}]$, where $\mathrm{C}$ is the growth of the fungal mycelium (in centimeters) toward the control and $\mathrm{T}$ is the growth of the fungal mycelium (in centimeters) toward the bacterial colony. The experiment was repeated thrice.

Antifungal traits. The ability of Gram-negative bacteria to produce cellulases, proteases, and siderophores was detected on carboxymethyl cellulase agar, skim milk agar (Dinesh et al. 2015), and chrome azurol S agar (Schwyn and Neilands 1987), respectively. A spot of $2 \mu \mathrm{l}$ of freshly grown culture was made on the agar media and placed in an incubator at $37^{\circ} \mathrm{C}$ for $72 \mathrm{~h}$. Halo zone formation transparent for protease and cellulase, which appeared after staining/destaining (Dinesh et al. 2015) while orange for siderophores, depicted the secretion of respective enzymes and siderophores. Production of each antifungal compound was expressed in terms of the substrate solubilization/discoloration index, which was computed as described in the previous section on nutrient solubilization. The experiment was performed in triplicate and repeated thrice.

Scoring of bacteria based on PGP traits. Bacteria were scored on the basis of their PGP characteristics. A criterion was developed for scoring on their individual PGPR trait (Supplementary Table S1). The strains with a maximum PGPR score were evaluated in planta.

In planta experiments. The effects of potential PGPR HU-8 and HU-9 were assessed on two wheat varieties, Pirsbak-2015 and Galaxy2013, against the challenge inoculation of $F$. oxysporum and F. moniliforme in petri plate experiments and pot experiments. Four independent experiments (two petri plate and two pot experiments) were laid out as a complete randomized design. In each experiment, there were four treatments with three replications per treatment $(n=3)$ for each wheat variety as follows: $\mathrm{T} 1=$ pathogen (F. moniliforme or $F$. oxysporum), T2 = fungicide (thiophanate methyl), T3 = HU-8 plus pathogen, and T4 = HU-9 plus pathogen. The sterilized seeds of both varieties were dipped in a bacterial suspension consisting of $5 \times 10^{9} \mathrm{CFU} / \mathrm{ml}$ for 2 to $3 \mathrm{~h}$ and sown in petri plates filled with Murashige and Skoog (MS) agar as well as in pots filled with sterilized soil (structure, clay loam; total nitrogen, 0.03 to $0.05 \%$; phosphorous, 12 to $14 \mathrm{mg} / \mathrm{kg}$; $\mathrm{pH}, 7.7$ to 7.9 ; and organic matter, 0.6 to $0.8 \%$ ). The fungicide was also applied as seed dressing by following the dose recommended by the manufacturer. The nitrogen, phosphorous, and potassium fertilizer was applied at the rate of 120,100 , and $60 \mathrm{~kg} / \mathrm{ha}$, respectively, in the form of urea, single super phosphate, and sulfate of potash (Ramzani et al. 2016). The petri plate experiments were repeated thrice but the pot experiments were repeated twice.

Fungal inoculation. In the petri plate experiments, a 5-mm mycelium plug of freshly grown fungi (F. oxysporum or F. moniliforme) 
was placed at the center of each plate and incubated at $25 \pm 3^{\circ} \mathrm{C}$. In the pot experiments, pathogens ( $F$. moniliforme or $F$. oxysporum) were inoculated by the soil drench method. Five milliliters of spore suspension consisting of approximately $10^{5}$ spores/ml was drenched in soil near the roots of emerging seedlings ( 2 weeks old) as described in earlier studies (Jaber 2018; Motallebi et al. 2015). The inoculated pots were placed in a net house under natural conditions.

Antioxidant enzyme activity. Antioxidant enzyme activity was determined at $24 \mathrm{~h}$ after fungal inoculation. Ten plants were harvested and a composite sample was made by grinding the leaves and stalk of the plants. One gram of composite sample was processed to compute the activity of polyphenol oxidase (PPO), peroxidase (PO), and phenylalanine ammonia lyase (PAL) enzymes. PPO, PO, and PAL enzymes were extracted by mixing the wheat tissues ( $1 \mathrm{~g})$ in different buffers, such as sodium phosphate buffer ( $\mathrm{pH} 6.5$ for PPO), potassium phosphate buffer ( $\mathrm{pH} 6.0$ for PO), and borate buffer (pH 8.8 for PAL). Enzyme activity was measured spectrophotometrically (Hassan et al. 2015). Enzyme activity was expressed as changes in the absorbance in minutes per gram of fresh weight of tissue.

Disease severity index and growth parameters. Disease was assessed visually at 14 to 15 days after fungal inoculation when the symptoms were clearly visible in control plants. Ten to twelve plants per treatment were randomly selected and disease was scored using the following 4-point scale, which is reported in numerous studies (Jaber 2018; Motallebi et al. 2015): 0, symptomless; 1, mild browning on roots/stem; 2, moderate browning (25 to $50 \%$ ); 3 , severe browning ( $>50 \%)$; and 4 , severe browning with completely rotten or dead plant tissues. The disease severity index (DI) was calculated as described by Lounaci et al. (2016): $\mathrm{DI}=[(0 \times \mathrm{F} 0)+$ $(1 \times \mathrm{F} 1)+(2 \times \mathrm{F} 2)+(3 \times \mathrm{F} 3)] / N$, where $\mathrm{F}$ is the number of plants for each disease score and $N$ is the total number of plants.

Plant growth parameters (e.g., root/shoot length) were measured with a scale, whereas fresh weight and dried weight were recorded on an electronic balance scale (Shimadzu).

Root colonization. The ability of inoculated bacterial strains to colonize wheat root rhizosphere grown in pots was determined at the time of disease assessment as described in our previous studies (Hassan et al. 2015; Rais et al. 2016). The composite samples of rhizosphere and endosphere were made by pooling the different plant parts per replication. The inoculated rhizobacteria were isolated by making the serial dilutions as described in the previous section on isolation of bacteria. The isolated colonies were counted and identified on the basis of their respective characteristics (i.e., nutrient solubilization and antagonism).

Molecular identification of PGPR. PGPR are identified at the genus level by sequence analysis of the $16 \mathrm{~S} r R N A$ gene. The $16 \mathrm{~S}$ $r R N A$ gene was amplified by using universal primers P1 and P6 (Tan et al. 1997). The PCR products were purified using a PCR purification kit (Thermo Scientific) and were sent to Macrogen Inc. in Korea for sequencing. The reverse sequence was complemented at JustBio (http://justbio.com) and aligned with the forward sequence at multiple sequence alignment (ClustalW). Both sequences were joined after removing the overlapping region and subjected to BLAST analysis using NCBI/EzTaxon (Altschul et al. 1990; Mekadim et al. 2018). The strains were identified on the basis of their closest type strains (Kim et al. 2012). The strains exhibiting maximum PGP traits and/or belonging to Pseudomonas spp. were further identified at the species level by sequencing the housekeeping gene $(r p o D)$. The primers were designed by aligning the $r p o D$ sequences of different Pseudomonas spp. About 20 to 25 consensus nucleotides were selected as forward ( $r p o D$ F:5'-ATGTCCGG AAAAGCGCAACAGCA-3') and reverse (rpoD R:'TCACTCGTC GAGGAAGGAGC') primers for the amplification of $r p o D$. PCR mixtures with a final volume of $50 \mu \mathrm{l}$ consisted of $32.5 \mu \mathrm{l}$ of sterile PCR water (Carl Roth), $5 \mu$ of Taq buffer (10×), $4 \mu$ of $\mathrm{MgCl}_{2}$ $(25 \mathrm{mM}), 3 \mu \mathrm{l}$ of dNTPs $(10 \mathrm{mM}), 2 \mu \mathrm{l}$ of each primer $(100 \mathrm{pM})$, $0.5 \mu$ of DNA Taq polymerase (500 U; Thermo Fisher Scientific), and $3 \mu \mathrm{l}$ of template DNA (30 ng/ $\mu \mathrm{l})$. Amplifying conditions consisted of initial denaturation at $95^{\circ} \mathrm{C}$ for $5 \mathrm{~min}$, annealing temperature at $65^{\circ} \mathrm{C}$ for $45 \mathrm{~s}$, and final extension at $72^{\circ} \mathrm{C}$ for $11 \mathrm{~min}$ and $30 \mathrm{~s}$ for 25 cycles. The amplified genes were purified, sequenced, and analyzed as described above. The strains were identified by BLAST analysis of the gene sequences (Altschul et al. 1990; Mekadim et al. 2018).

\section{RESULTS}

Wheat rhizospheric and endospheric bacteria. Twentynine bacterial isolates were obtained from the rhizosphere and endosphere of wheat. Based on the isolate source, 16 bacteria were isolated from the rhizosphere and 13 from the endosphere. Among these isolates, 12 were Gram negative and 17 were Gram positive. Most of the bacterial isolates $(n=16)$ were found in rhizosphere, followed by the spike endosphere $(n=8)$, root endosphere $(n=2)$, and leaf endosphere $(n=2)$. Only a single isolate was found in the stem endosphere $(n=1)$. Eight Gram-negative bacteria were found in the rhizosphere, whereas there were four in the spike endosphere.

Multifarious traits of rhizobacteria. Out of 12 Gramnegative isolates, only seven exhibited one or more PGP traits.

Nutrient solubilization. Six of seven strains showed phosphate solubilizing ability. Maximum phosphate solubilization was shown by HU-5 (solubilization zone $=3.31 \mathrm{~mm}$ ), followed by HU-8 (3.18 mm); HU-6 showed minimum solubilization $(2.33 \mathrm{~mm})$. Intermediate phosphate solubilization was shown by $\mathrm{HU}-1$ (solubilization zone $=2.48 \mathrm{~mm})$, HU-4 $(2.51 \mathrm{~mm})$, and HU-7 (2.6 mm) (Table 1). HU-9 did not solubilize the phosphate. Five of seven strains solubilized the zinc. Maximum zinc solubilization was performed by HU-4 (solubilization zone $=4.06 \mathrm{~mm}$ ); the rest of the solubilizers showed an almost similar solubilization (HU-6, $2.68 \mathrm{~mm}$; HU-5, $2.62 \mathrm{~mm}$; HU-9, $2.47 \mathrm{~mm}$; and HU-7, $2.42 \mathrm{~mm}$ ) (Table 1). All of the isolates were unable to solubilize potassium.

Fungal antagonism. The isolated bacteria showed antagonistic effects against four phytopathogenic fungi: $F$. moniliforme, F. oxysporum, P. oryzae, and M. phaseolina. Four of seven bacterial

TABLE 1. Plant growth-promoting traits of wheat associated bacteria ${ }^{y}$

\begin{tabular}{|c|c|c|c|c|c|c|c|c|c|}
\hline \multirow[b]{3}{*}{ Isolate code } & \multirow[b]{3}{*}{ Source } & \multirow[b]{3}{*}{ Phenotype ${ }^{z}$} & \multirow{2}{*}{\multicolumn{2}{|c|}{$\begin{array}{c}\text { Nutrient } \\
\text { solubilization }\end{array}$}} & \multirow{2}{*}{\multicolumn{3}{|c|}{ Antifungal compound }} & \multicolumn{2}{|c|}{ Fungal antagonism } \\
\hline & & & & & & & & \multirow{2}{*}{$\begin{array}{l}\text { Fusarium } \\
\text { oxysporum }\end{array}$} & \multirow[b]{2}{*}{ F. moniliforme } \\
\hline & & & Phosphate & Zinc & Protease & Cellulase & Siderophore & & \\
\hline HU-1 & Rhizosphere & Circular, moist, colorless & $2.48 \mathrm{~b}$ & $0.00 \mathrm{~d}$ & $0.00 \mathrm{c}$ & $4.73 \mathrm{a}$ & $2.85 \mathrm{~b}$ & $0.00 \mathrm{~d}$ & $00.00 \mathrm{c}$ \\
\hline HU-4 & Rhizosphere & Filamentous, filiform, colorless & $2.51 \mathrm{~b}$ & $4.05 \mathrm{a}$ & $2.41 \mathrm{a}$ & $3.74 \mathrm{~b}$ & $0.00 \mathrm{c}$ & $28.33 \mathrm{c}$ & $0.00 \mathrm{c}$ \\
\hline HU-5 & Rhizosphere & Circular, moist, yellow & $3.31 \mathrm{a}$ & $2.62 \mathrm{~b}$ & $0.00 \mathrm{c}$ & $0.00 \mathrm{e}$ & $0.00 \mathrm{c}$ & $0.00 \mathrm{~d}$ & $0.00 \mathrm{c}$ \\
\hline HU-6 & Rhizosphere & Circular, moist, colorless & $2.33 \mathrm{~b}$ & $2.68 \mathrm{~b}$ & $0.00 \mathrm{c}$ & $3.10 \mathrm{c}$ & $0.00 \mathrm{c}$ & $0.00 \mathrm{~d}$ & $0.00 \mathrm{c}$ \\
\hline HU-7 & Rhizosphere & Irregular, dry, colorless & $2.6 \mathrm{~b}$ & $2.42 \mathrm{c}$ & $2.2 \mathrm{~b}$ & $0.00 \mathrm{e}$ & $0.00 \mathrm{c}$ & $28.33 \mathrm{c}$ & $37.5 \mathrm{~b}$ \\
\hline HU-8 & Rhizosphere & Circular, moist, green & $3.18 \mathrm{a}$ & $0.00 \mathrm{~d}$ & $2.2 \mathrm{~b}$ & $0.00 \mathrm{e}$ & $3.33 \mathrm{a}$ & $45.5 \mathrm{a}$ & $40.43 \mathrm{a}$ \\
\hline HU-9 & Endosphere & Irregular, moist, orange & $0.00 \mathrm{c}$ & $2.47 \mathrm{c}$ & $2.35 \mathrm{a}$ & $2.25 \mathrm{~d}$ & $0.00 \mathrm{c}$ & $40.33 \mathrm{~b}$ & $40.83 \mathrm{a}$ \\
\hline
\end{tabular}

y Values are the mean of three replicates and those bearing different letters in the same column are significantly different at $P \leq 0.05$.

z Colony morphology was observed on Luria Bertani agar. 
isolates inhibited the growth of F. oxysporum. Maximum inhibition was shown by HU-8 (45.45\%), followed by HU-9 (40.39\%); minimum inhibition was shown almost equally by HU-4 $(28.27 \%)$ and HU-7 (27.8\%), as shown in Table 1. Only three strains inhibited F. moniliforme. Maximum inhibition (40.83\%) was shown by HU-8 and HU-9 followed by HU-7 (37.5\%). Strain HU-8 also antagonized P. oryzae (43.2\%) and M. phaseolina (25\%), whereas strain HU-9 only antagonized $P$. oryzae $(45.5 \%)$.

Production of antifungal traits. The bacterial isolates exhibited the major antifungal traits such as cellulases, proteases, and siderophores. Maximum cellulase was secreted by HU-1 ( solubilization zone $=4.7 \mathrm{~mm}$ ) followed by HU-5 $(3.74 \mathrm{~mm})$. Intermediate secretion was shown by HU-6 $(3.1 \mathrm{~mm})$, whereas minimum secretion was observed for HU-9 $(2.25 \mathrm{~mm})$ (Table 1). Three strains (e.g., HU-4, HU-7, and HU-8) did not secrete cellulase. Production of siderophores was shown by only two strains: HU-8 (discoloration zone $=3.32 \mathrm{~mm})$ and HU-1 $(2.85 \mathrm{~mm})$. Protease production was observed for four strains, with the maximum by HU-4 (solubilization zone $=2.41 \mathrm{~mm}$ ) followed by that of HU-9 (2.35 mm), HU-7, and HU-8 (2.2 mm each) (Table 1).

Selection of potential PGPR. On a scoring scale of 9 based on PGP activities, isolates HU-8 and HU-9 showed maximum scores of 6 to 7, whereas HU-1, HU-5, and HU-6 showed a minimum score of 3 (Supplementary Fig. S1).

Growth promotion and biocontrol activity on wheat. Isolates HU-8 and HU-9 significantly promoted the growth of wheat and reduced disease on both varieties (Pirsbak-2015 and Galaxy-2013). Strains HU-8 and HU-9 showed an increase in all plant parameters of wheat infected with $F$. moniliforme at par to that of fungicide. They increased the fresh weight by 75 to $77 \%$ and dry weight by 37 to $51 \%$ over the control in both experiments (Table 2). F. oxysporum-infected wheat plants inoculated with HU-8 and HU-9 showed a significant increase in root/leaf length and fresh/dry weight. The isolates showed enhancement in root length by 43 to $49 \%$ and 67 to $77 \%$, leaf length by 33 to $41 \%$ and 22 to $39 \%$, and fresh weight by 65 to $67 \%$ and 46 to
$84 \%$ in the plate and pot experiments, respectively, compared with the control infected wheat plants. This effect was statistically similar to that of fungicide (Table 3 ).

Induction of antioxidant enzymes. Isolates HU-8 and HU-9 significantly induced antioxidant enzyme activity in wheat varieties Pirsbak-2015 and Galaxy-2013 challenged with phytopathogens $F$. oxysporum and $F$. moniliforme in the petri plate and pot experiments (Figs. 1 and 2).

PO activity. PGP strains significantly enhanced $\mathrm{PO}$ activity in both experiments. Higher PO activity in the pot experiments was observed for HU-8 (1.2-fold) against $F$. oxysporum in wheat variety Pirsbak-2015 followed by HU-9 (1-fold) against $F$. moniliforme in Pirsbak-2015, whereas the lowest PO activity was observed for HU-9 (0.2-fold) against $F$. oxysporum in variety Galaxy-2013. A similar trend was observed in the plate assay. However, the induction of PO enzyme was slightly higher in the pot experiments $(0.2-$ to 1.2 -fold) compared with the plate assay (0.3- to 0.9 -fold). PO activity in fungicide-treated plants was slightly lower (0.17 to 0.7$)$ than that of bacteria-treated plants (Figs. 1 and 2).

PPO activity. The PGP strains induced PPO activity in all experimental conditions. In the pot experiments, maximum PPO activity was observed for HU-9 (2.1-fold) against $F$. moniliforme in variety Galaxy-2013 followed by HU-8 and HU-9 (1.5-fold each) against $F$. oxysporum in Galaxy-2013 and $F$. moniliforme in variety Pirsbak-2015, respectively, and HU-8 (1.1-fold) against $F$. oxysporum in Galaxy-2013. Minimum PPO activity was observed for HU-9 (0.5-fold) against $F$. moniliforme in Pirsbak-2015 (Figs. 1 and 2). However, the induction of PPO enzyme was slightly higher in the pot experiments (0.5- to 2.1-fold) compared with the plate assay (0.6- to 1.9-fold). The PPO activity in fungicide-treated plants was either at par to that of the bacterial strains or slightly lower, as shown in Figures 1 and 2.

PAL activity. The PGP strains significantly induced PAL activity upon fungal challenge. In the pot experiments, maximum PAL activity was shown by HU-8 (1.8-fold) against $F$. oxysporum in

TABLE 2. Effect of rhizobacteria on the growth of wheat challenged with Fusarium moniliforme ${ }^{\mathrm{z}}$

\begin{tabular}{|c|c|c|c|c|c|c|c|c|c|c|}
\hline \multirow[b]{2}{*}{ Treatment } & \multicolumn{2}{|c|}{ Root length (cm) } & \multicolumn{2}{|c|}{ Shoot length $(\mathrm{cm})$} & \multicolumn{2}{|c|}{ Leaf length (cm) } & \multicolumn{2}{|c|}{ Fresh weight (g) } & \multicolumn{2}{|c|}{ Dry weight (g) } \\
\hline & Plate exp. & Pot exp. & Plate exp. & Pot exp. & Plate exp. & Pot exp. & Plate exp. & Pot exp. & Plate exp. & Pot exp. \\
\hline \multicolumn{11}{|c|}{ Galaxy-2013 } \\
\hline $\mathrm{T} 1$ & $7.67 \mathrm{c}$ & $17.44 \mathrm{c}$ & $4.83 \mathrm{~b}$ & $5.78 \mathrm{~b}$ & $9.67 \mathrm{~b}$ & $19.80 \mathrm{a}$ & $0.12 \mathrm{~b}$ & $1.16 \mathrm{~b}$ & $0.01 \mathrm{~b}$ & $0.41 \mathrm{c}$ \\
\hline $\mathrm{T} 3$ & $10.00 \mathrm{~b}$ & $29.63 \mathrm{~b}$ & $5.33 \mathrm{ab}$ & $10.17 \mathrm{a}$ & $15.17 \mathrm{a}$ & $23.32 \mathrm{a}$ & $0.15 \mathrm{~b}$ & $2.16 \mathrm{a}$ & $0.02 \mathrm{~b}$ & $0.84 \mathrm{~b}$ \\
\hline $\mathrm{T} 4$ & $11.83 \mathrm{ab}$ & $31.77 \mathrm{a}$ & $5.67 \mathrm{ab}$ & $10.37 \mathrm{a}$ & $16.83 \mathrm{a}$ & $21.48 \mathrm{a}$ & $0.24 \mathrm{a}$ & $2.19 \mathrm{a}$ & $0.02 \mathrm{a}$ & $0.99 \mathrm{a}$ \\
\hline \multicolumn{11}{|c|}{ Pirsbak-2015 } \\
\hline T3 & $14.00 \mathrm{bc}$ & $32.37 \mathrm{a}$ & $5.67 \mathrm{a}$ & $8.59 \mathrm{a}$ & $14.16 \mathrm{a}$ & $20.76 \mathrm{a}$ & $0.16 \mathrm{a}$ & $1.67 \mathrm{a}$ & $0.02 \mathrm{a}$ & $0.68 \mathrm{a}$ \\
\hline $\mathrm{T} 4$ & $16.83 \mathrm{a}$ & $28.56 \mathrm{~b}$ & $4.83 \mathrm{~b}$ & $8.98 \mathrm{a}$ & $13.67 \mathrm{a}$ & $19.20 \mathrm{ab}$ & $0.17 \mathrm{a}$ & $1.41 \mathrm{a}$ & $0.02 \mathrm{a}$ & $0.62 \mathrm{ab}$ \\
\hline
\end{tabular}

$\mathrm{z}$ Values are the mean of three replicates and those bearing different letters in the same column are significantly different at $P \leq 0.05$. exp $=\operatorname{experiment,~T1~}=$ pathogenic fungi (control), T2 = fungicide plus pathogenic fungi, $\mathrm{T} 3=\mathrm{HU}-8$ plus pathogenic fungi, and $\mathrm{T} 4=\mathrm{HU}-9$ plus pathogenic fungi.

TABLE 3. Effect of rhizobacteria on the growth of wheat challenged with Fusarium oxysporum ${ }^{\mathrm{z}}$

\begin{tabular}{|c|c|c|c|c|c|c|c|c|c|c|}
\hline \multirow[b]{2}{*}{ Treatment } & \multicolumn{2}{|c|}{ Root length $(\mathrm{cm})$} & \multicolumn{2}{|c|}{ Shoot length $(\mathrm{cm})$} & \multicolumn{2}{|c|}{ Leaf length $(\mathrm{cm})$} & \multicolumn{2}{|c|}{ Fresh weight (g) } & \multicolumn{2}{|c|}{ Dry weight (g) } \\
\hline & Plate exp. & Pot exp. & Plate exp. & Pot exp. & Plate exp. & Pot exp. & Plate exp. & Pot exp. & Plate exp. & Pot exp. \\
\hline \multicolumn{11}{|c|}{ Galaxy-2013 } \\
\hline $\mathrm{T} 1$ & $6.67 \mathrm{~b}$ & $14.32 \mathrm{~b}$ & $5.73 \mathrm{a}$ & $5.80 \mathrm{c}$ & $11.00 \mathrm{~b}$ & $16.89 \mathrm{c}$ & $0.08 \mathrm{~b}$ & $1.25 \mathrm{~b}$ & $0.014 \mathrm{~b}$ & $0.43 \mathrm{c}$ \\
\hline $\mathrm{T} 2$ & $10.99 \mathrm{a}$ & $34.80 \mathrm{a}$ & $6.31 \mathrm{a}$ & $9.45 \mathrm{a}$ & $14.80 \mathrm{a}$ & $21.16 \mathrm{ab}$ & $0.13 \mathrm{a}$ & $1.46 \mathrm{ab}$ & $0.016 \mathrm{ab}$ & $0.63 \mathrm{ab}$ \\
\hline $\mathrm{T} 3$ & $10.67 \mathrm{a}$ & $32.59 \mathrm{a}$ & $5.17 \mathrm{a}$ & $8.167 \mathrm{~b}$ & $15.17 \mathrm{a}$ & $20.67 \mathrm{~b}$ & $0.14 \mathrm{a}$ & $1.58 \mathrm{a}$ & $0.015 \mathrm{ab}$ & $0.67 \mathrm{a}$ \\
\hline $\mathrm{T} 4$ & $11.00 \mathrm{a}$ & $27.83 \mathrm{a}$ & $5.83 \mathrm{a}$ & $8.89 \mathrm{ab}$ & $16.00 \mathrm{a}$ & $23.56 \mathrm{a}$ & $0.16 \mathrm{a}$ & $1.55 \mathrm{a}$ & $0.018 \mathrm{a}$ & $0.60 \mathrm{~b}$ \\
\hline \multicolumn{11}{|c|}{ Pirsbak-2015 } \\
\hline $\mathrm{T} 1$ & $11.33 \mathrm{~b}$ & $19.00 \mathrm{c}$ & $5.17 \mathrm{ab}$ & $5.89 \mathrm{~b}$ & $11.17 \mathrm{~b}$ & $17.28 \mathrm{a}$ & $0.12 \mathrm{~b}$ & $0.67 \mathrm{~b}$ & $0.007 \mathrm{~b}$ & $0.47 \mathrm{~b}$ \\
\hline $\mathrm{T} 2$ & $14.84 \mathrm{ab}$ & $29.85 \mathrm{a}$ & $5.46 \mathrm{ab}$ & $8.04 \mathrm{a}$ & $13.14 \mathrm{ab}$ & $18.83 \mathrm{a}$ & $0.16 \mathrm{ab}$ & $1.01 \mathrm{~b}$ & $0.016 \mathrm{a}$ & $0.57 \mathrm{ab}$ \\
\hline T3 & $15.00 \mathrm{ab}$ & $29.33 \mathrm{ab}$ & $4.83 \mathrm{~b}$ & $7.15 \mathrm{a}$ & $14.33 \mathrm{a}$ & $19.72 \mathrm{a}$ & $0.19 \mathrm{a}$ & $1.53 \mathrm{a}$ & $0.018 \mathrm{a}$ & $0.67 \mathrm{a}$ \\
\hline $\mathrm{T} 4$ & $15.67 \mathrm{a}$ & $26.18 \mathrm{~b}$ & $5.83 \mathrm{a}$ & $6.18 b$ & $15.17 \mathrm{a}$ & $19.50 \mathrm{a}$ & $0.18 \mathrm{a}$ & $0.84 \mathrm{~b}$ & $0.018 \mathrm{a}$ & $0.567 \mathrm{ab}$ \\
\hline
\end{tabular}

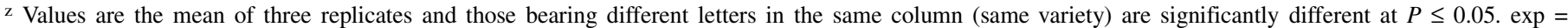
experiment, $\mathrm{T} 1$ = pathogenic fungi (control), T2 = fungicide plus pathogenic fungi, $\mathrm{T} 3=\mathrm{HU}-8$ plus pathogenic fungi, and $\mathrm{T} 4=\mathrm{HU}-9$ plus pathogenic fungi. 
Galaxy-2013 followed by HU-9 (1.5-fold) against F. moniliforme in Galaxy-2013, whereas the lowest activity was shown by HU-8 (0.5-fold) against $F$. oxysporum in Pirsbak-2015.

A different trend was observed in the plate assay. Maximum PAL activity was observed for HU-9 (1.8-fold) against $F$. moniliforme in Galaxy-2013 followed by HU-9 (1.3-fold) against $F$. oxysporum in Galaxy-2013, whereas the lowest activity was observed for HU-8 (0.2-fold) against $F$. oxysporum in Pirsbak-2015. The fungicide also induced PAL activity compared with that of the control (Figs. 1 and 2).

DI and root colonization. The tested strains showed significantly less disease severity against Fusarium spp. compared with the control on both wheat varieties. Their efficacy was either statistically at par or even better than that of fungicide (Fig. 3). The minimum disease score was observed for HU-9 (1.7 in Galaxy-2013 and 2.3 in Pirsbak-2015) followed by HU-8 (2.3 in Galaxy-2013 and 2.7 in Pirsbak-2015), as shown in Figure 3. Strains HU-8 and HU-9 significantly colonized the wheat plants with a cell population of 6.6 to $8.5 \mathrm{log} \mathrm{CFU} / \mathrm{g}$ of rhizospheric soil under the challenge inoculation of both fungi (Fig. 4). HU-9 was also an endophytic colonizer with a cell population of $4.5 \mathrm{log} \mathrm{CFU} / \mathrm{g}$ of roots, whereas HU-8 was unable to colonize the roots endophytically.

Principal component analysis. The data were subjected to a principal component analysis (Figs. 5 and 6). The biplot clearly demonstrated the correlation between different growth parameters, disease severity, and antioxidant enzyme activity of wheat with the inoculated strains.

Molecular identification of PGPR. 16S rRNA gene analysis. Gram-negative bacteria associated with wheat and exhibiting PGPR traits were found to be members of different genera. For example, strains HU-1 (MF347446), HU-8 (MF347453), and HU-9 (MF347454) were identified as Pseudomonas spp.; strains HU-5 (MF347450), HU-6 (MF347451), and HU-7 (MF347452) were identified as Ochrobactrum spp.; and HU-4 (MF347449) was identified as Acinetobacter spp.

rpoD gene sequence analysis. The Pseudomonas species HU-1, HU-8, and HU-9 were further identified at the species level by sequencing the housekeeping gene, $r p o D$. Strain HU-1 was identified as P. putida, whereas HU-8 and HU-9 were identified as $P$. mediterranea. The nucleotide sequences of all three strains were submitted to Genbank under accession numbers MF580376 to MF580378.

\section{DISCUSSION}

PGPR play a vital role in improving plant health either through aiding in the acquisition of essential soil nutrients or suppressing pathogens (Kim and Anderson 2018). In this study, rhizobacteria isolated from the wheat rhizosphere grown in a monocropping

\section{Petri-plate Experiment}

F. moniliforme

$\square \mathrm{T} 1 \square \mathrm{T} 2 \square \mathrm{T} 3 \square \mathrm{T} 4$

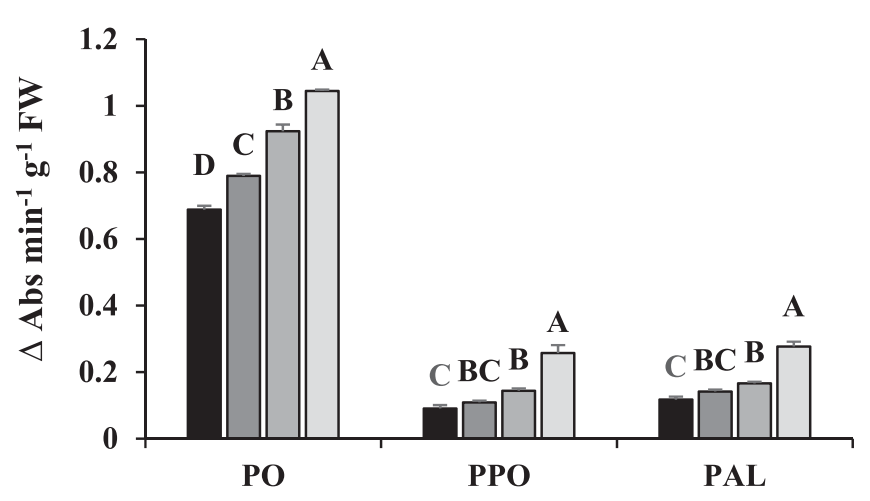

F. oxysporum

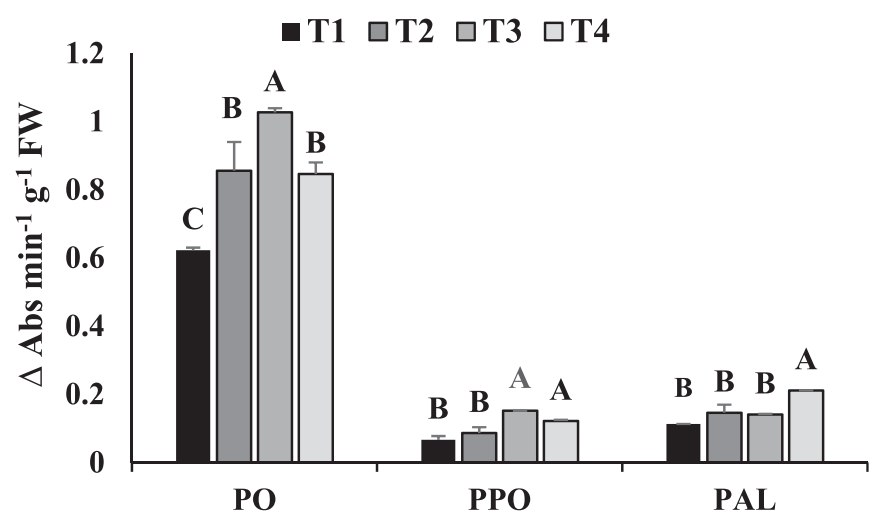

Pirsbak-2015
F. moniliforme

$\because \mathrm{T} 1 \square \mathrm{T} 2 \square \mathrm{T} 3 \square \mathrm{T} 4$

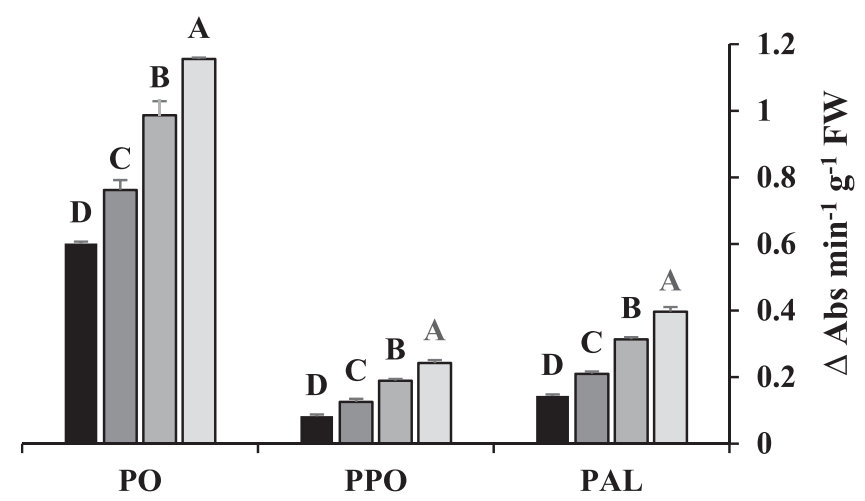

F. oxysporum

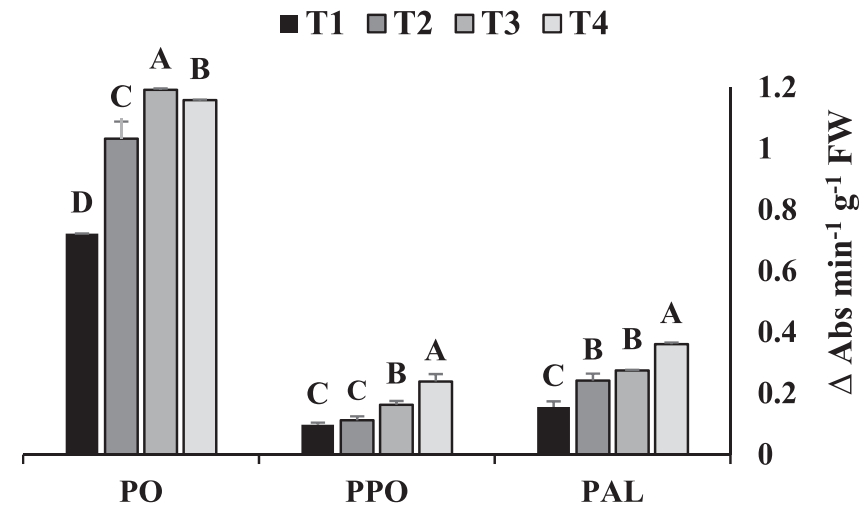

Galaxy-2013

Fig. 1. Rhizobacteria-mediated induction of antioxidant enzymes in wheat under the challenge inoculation of Fusarium spp. (petri plate experiment). $\Delta$ Abs $=$ change in absorbance, $\mathrm{FW}=$ fresh weight, $\mathrm{T} 1=$ pathogenic fungi (control), $\mathrm{T} 2=$ fungicide plus pathogenic fungi, $\mathrm{T} 3=\mathrm{HU}-8$ plus pathogenic fungi, and $\mathrm{T} 4=\mathrm{HU}-9$ plus pathogenic fungi. The Pirsbak-2015 and Galaxy-2013 varieties are shown in the graphs on the left and right, respectively. Values are the means of three replicates and those bearing different letters within the same enzyme (peroxidase [PO], polyphenol oxidase [PPO], and phenylalanine ammonia lyase [PAL]) are significantly different. Bars represent the standard error. 
system of an arid/semiarid agriculture zone exhibited multifarious traits and significantly controlled the root and/or crown rot of wheat. The population and diversity of rhizobacteria in certain crop rhizospheres/endospheres is highly dependent on multiple factors such as cultivar, cropping pattern, agriculture practices, and climate (Matthews et al. 2019; Na et al. 2019; Schlemper et al. 2018). In our findings, the culturable bacteria associated with wheat, cultivated in a monocropping system of arid zone agriculture, revealed a higher population in the root rhizosphere than that of the endosphere. These findings are supported by earlier reports showing that the plant rhizosphere/endosphere is the hotspot for microbial community (Truyens et al. 2015). The difference in population of endophytic and rhizospheric bacteria may be attributable to the potential of selective bacteria to effectively penetrate and adopt the host plant's tissues (Etesami et al. 2014; Mendes et al. 2007). The endophytic beneficial bacteria modulate the development and growth of the plants by eliciting different physiological changes (Van der Ent and Pieterse 2012). Low numbers of bacteria recovered from the leaf and spike endosphere may be attributable to many factors such as the challenges of habitat specificity and the limitations associated with culture-dependent isolation techniques (Truyens et al. 2015). The endophytic bacterial population densities are in concordance with earlier studies (Etesami et al. 2014; Mendes et al. 2007).
The high prevalence of Gram-negative PGPR in this study may be attributable to multiple reasons, such as (i) the harvesting stage of the wheat, where the only bacteria with predominant secondary metabolism can survive by tolerating the adverse environmental conditions, and (ii) the monocropping system, where wheat grown for successive years recruits the specific bacteria through exudation of specific compounds via roots (Cha et al. 2016). Root exudates favor the growth of selective microorganisms, resulting in their higher cell density in the rhizosphere (Cha et al. 2016; van der Voort et al. 2016). The PGPR prevailing in the wheat rhizosphere were less diverse. This is consistent with earlier reports showing that monocropping leads to changes in microbial communities (Zhao et al. 2018). Because the root exudate composition depends on the plant species, cultivar, and many environmental factors such as nutrient availability, temperature, $\mathrm{pH}$, and humidity, the bacterial diversity also varies from plant to plant (Bainard et al. 2013; Zhou et al. 2015).

The bacteria exhibited multiple PGP traits. The majority of the isolates showed phosphate solubilization but none showed potassium solubilization, although zinc solubilization was shown by few bacterial isolates. It has been well described that PGPR solubilize nutrients by releasing organic acids such as citric acid, oxalic acid, lactic acid, and gluconic acid (Han and Lee 2005; Khan et al. 2007). These organic acids result in the lowering of soil $\mathrm{pH}$,

\section{Pot Experiment}

F. moniliforme

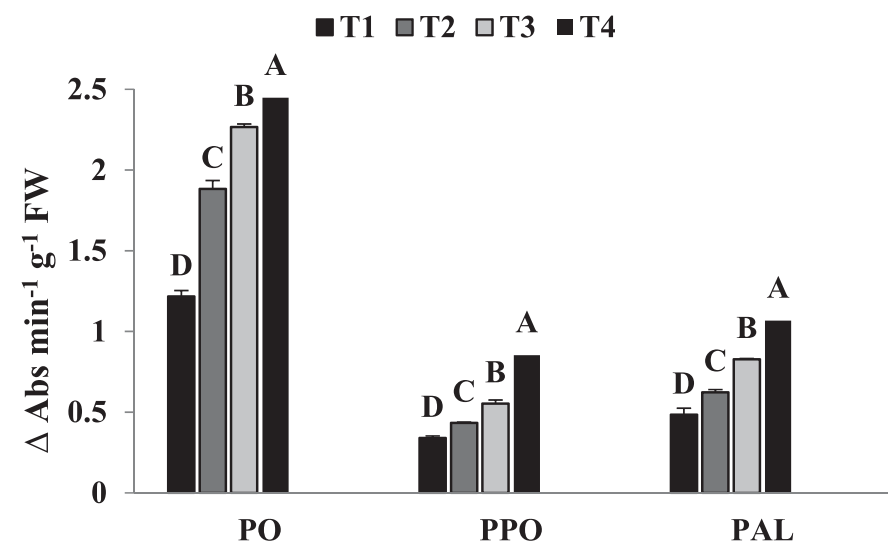

F. oxysporum

$\square \mathrm{T} 1 \square \mathrm{T} 2 \square \mathrm{T} 3 \square \mathrm{T} 4$

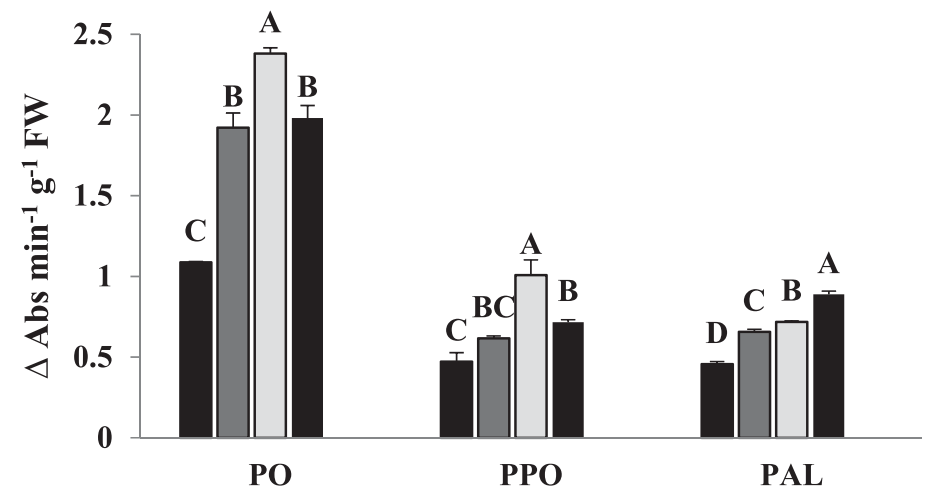

Pirsbak-2015

\section{F. moniliforme}

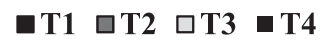

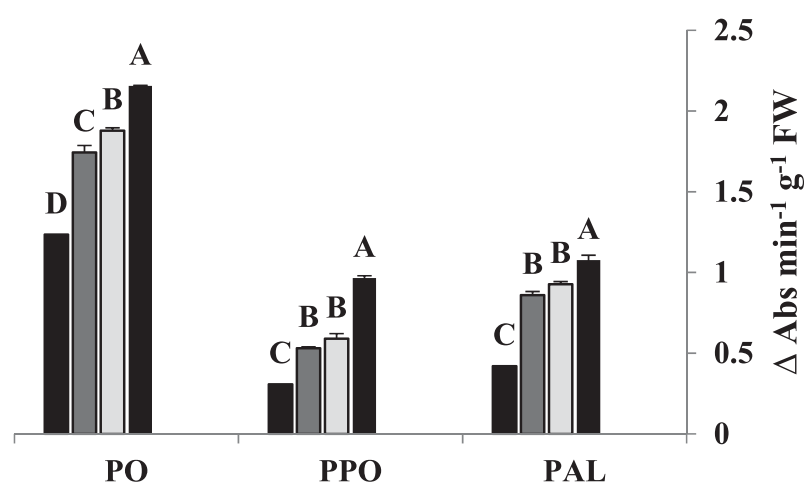

F. oxysporum

$\square \mathrm{T} 1 \square \mathrm{T} 2 \square \mathrm{T} 3 \square \mathrm{T} 4$

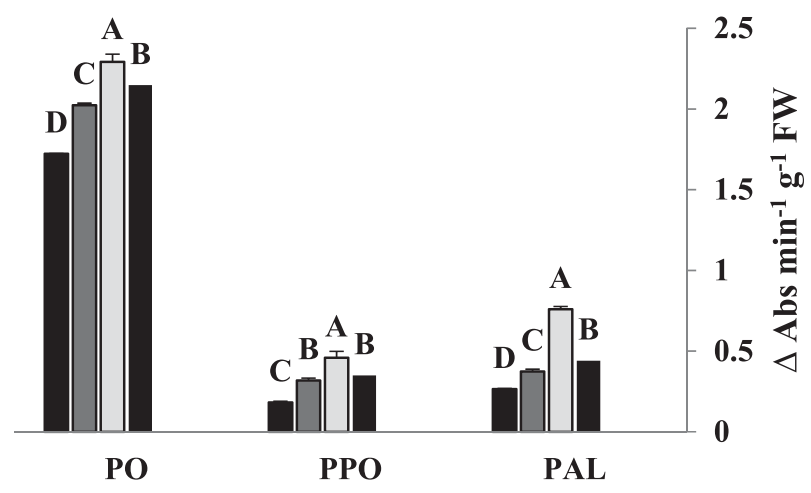

Galaxy-2013

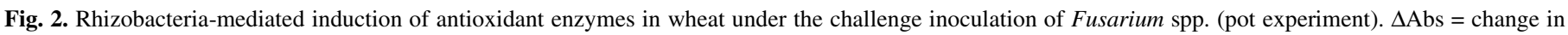

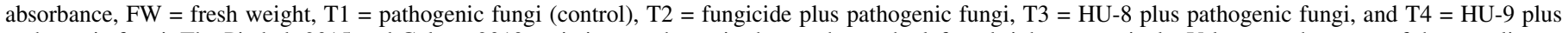

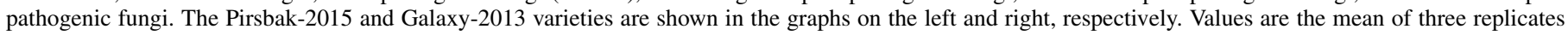

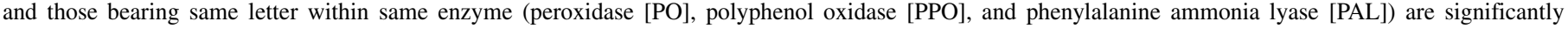
different. Bars represent standard error. 
which favors the solubilization of phosphorous and zinc, whereas the maximum potassium solubilization occurs at neutral $\mathrm{pH}$ (de Werra et al. 2009; Lukkani and Reddy 2015; Parmar and Sindhu 2013). The possible reason for the inability of bacterial isolates to solubilize potassium is either the lowering of $\mathrm{pH}$ through secretion of organic acids or the physiological differences among isolates. However, this needs to be explored in further studies. The antagonistic activity of PGPR against four pathogenic fungi (F. oxysporum, F. moniliforme, P. oryzae, and M. phaseolina) was associated with the production of certain metabolites and/or compounds. The bacterial strains producing moderate levels of hydrolytic enzymes (e.g., cellulase, protease) and the maximum level of siderophores inhibited all of the tested phytopathogens, whereas the strains that produced the hydrolytic enzymes but not siderophores could not inhibit all pathogens. This result shows that the competition for the iron resource is a major antifungal mechanism, as reported earlier (Lambrese et al. 2018; Sharma and Johri 2003). The strains that produced only protease enzyme were able to moderately inhibit only two fungi ( $F$. oxysporum and F. moniliforme) but strains that produced only cellulase were unable to inhibit any of the fungi. This revealed the limitation of hydrolytic enzyme in biocontrol activity owing to their substrate specificity present in the targeted pathogen (Marin-Bruzos and Grayston 2019). These findings also predict that the antifungal compounds work synergistically to eliminate the fungal pathogens. However, their production and regulation is an interesting era of research under the "metabolic coregulation" domain. The bacterial strains exhibiting the best PGPR traits in vitro also significantly colonized the wheat rhizosphere and suppressed root and crown rot disease. These findings are inconsistent with earlier studies in which rhizobacteria successfully suppressed wheat root rot (Barnett et al. 2019; Shikur Gebremariam et al. 2018).

As depicted by the rhizobacterial effect on disease development, rhizobacteria could be an ideal substituent to the fungicides that pose severe environmental threats upon their irrational use (Upadhyay et al. 2018). This claim is supported by earlier reports in which PGPR effectively controlled economically important diseases like red rot caused by $C$. falcatum and blast disease caused by $P$. oryzae (Hassan et al. 2015; Rais et al. 2016). The root-colonizing ability of bacteria is strongly related to the production of their secondary metabolites by which they tolerate environmental stress (Bajpai and Johri 2019; Mehmood et al. 2019; Ramawat and Goyal 2019; Thomashow et al. 2019). Optimum population of bacterial cells $\left(10^{6}\right.$ to $10^{7} \mathrm{CFU} / \mathrm{g}$ of soil) is necessary for the beneficial plant-microbe interaction (Hassan et al.
匹 Galaxy-2013 $\square$ Pirsbak-2015

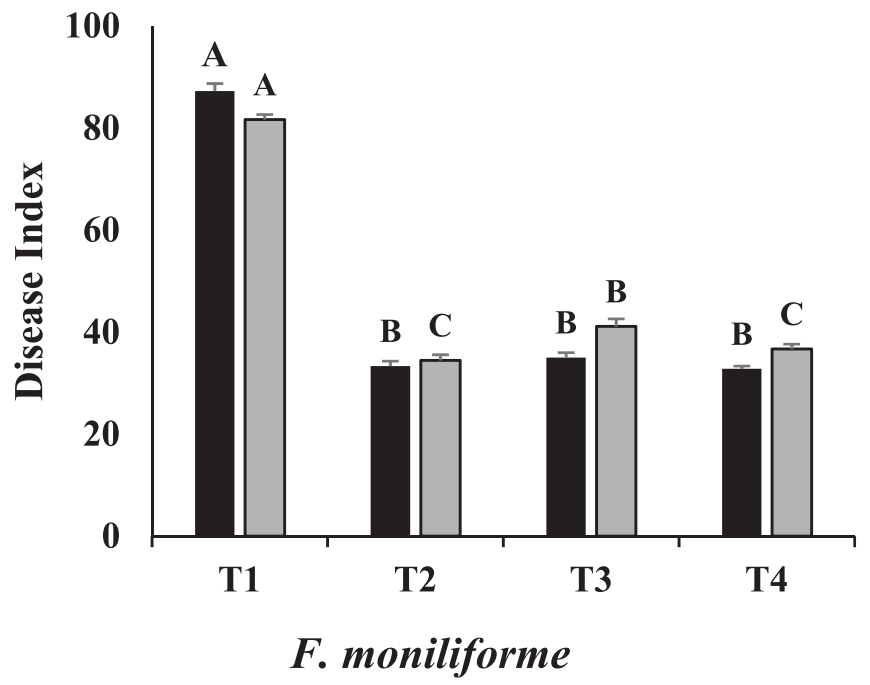

— Galaxy-2013 $\square$ Pirsbak-2015

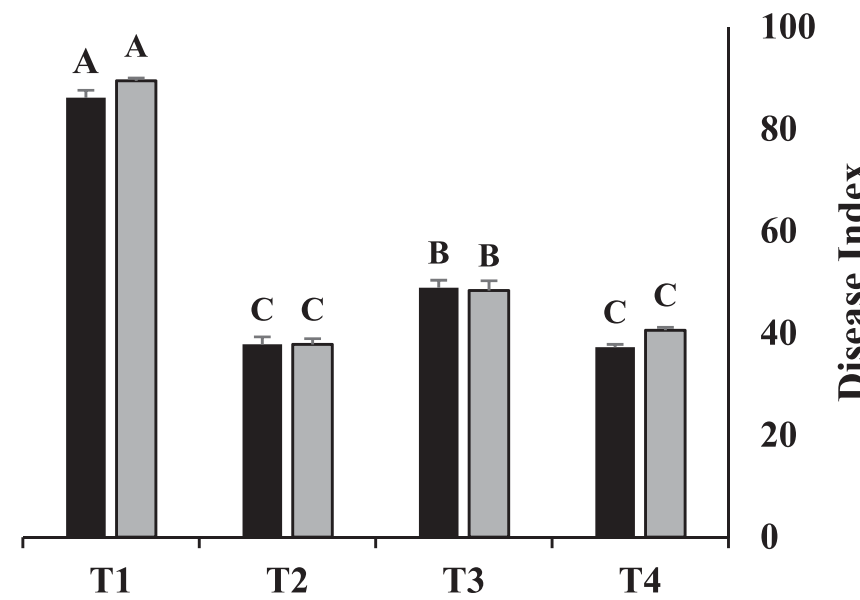

F. oxysporum

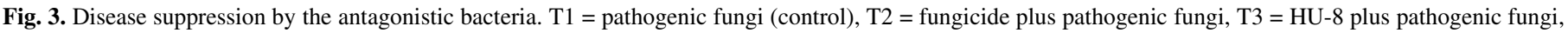

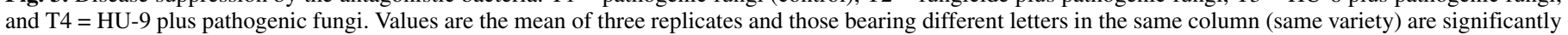
different from each other at $P \leq 0.05$.

口 Galaxy-2013 $\square$ Pirsbak-2015

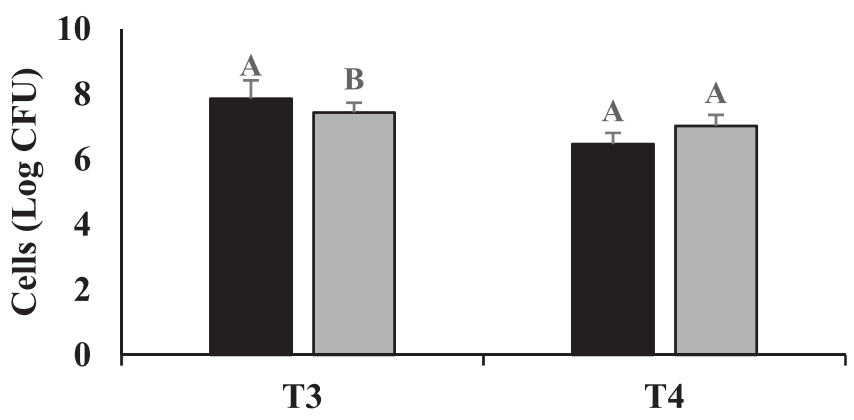

F. moniliforme
- Galaxy-2013 $\square$ Pirsbak-2015

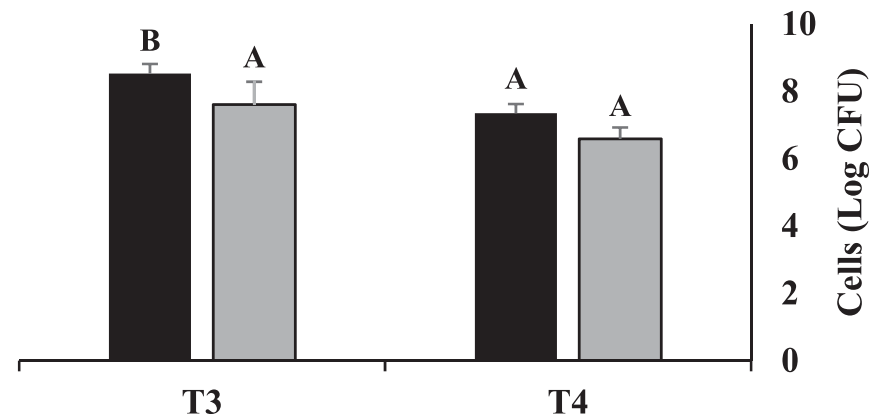

\section{F. oxysporum}

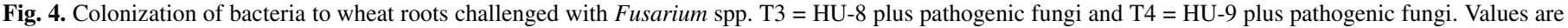
the mean of three replicates and those bearing different letters in the same column (same variety) are significantly different from each other at $P \leq 0.05$. 


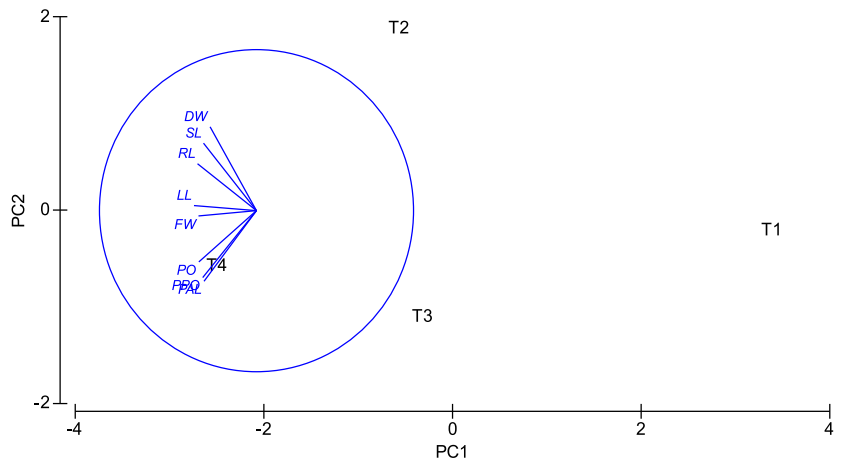

F. oxysporum

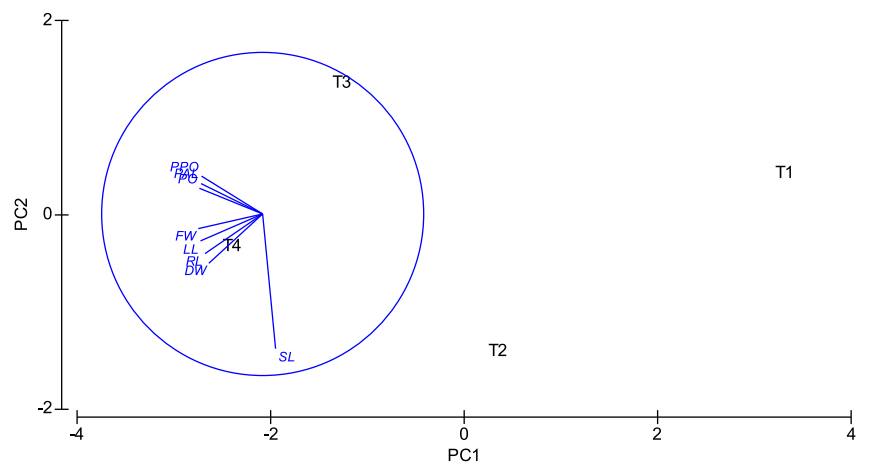

Galaxy- 2013

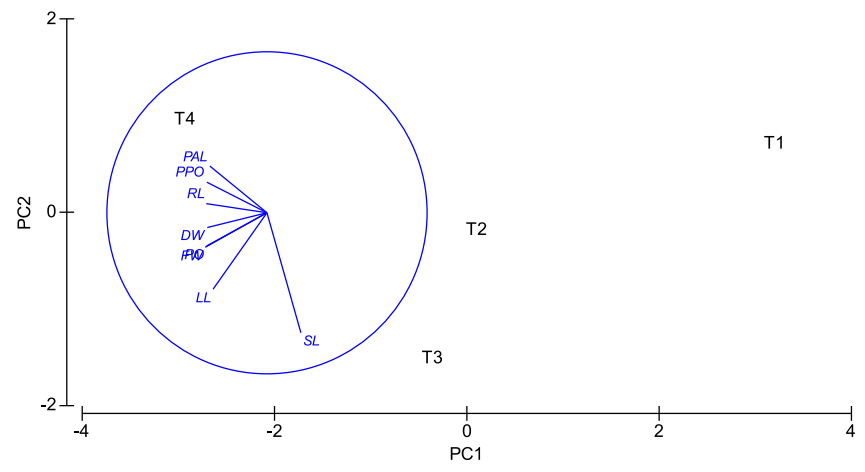

F. oxysporum

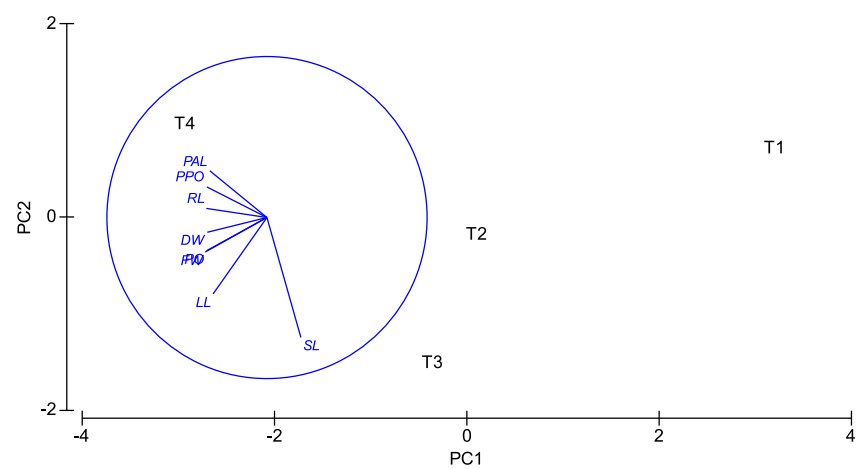

Pirsbak- 2015

Fig. 5. Principal component $(\mathrm{PC})$ analysis between the rhizobacteria and their in planta plant growth-promoting traits (petri plate experiment). $\mathrm{T} 1=$ pathogenic fungi (control), T2 = fungicide plus pathogenic fungi, T3 = HU-8 plus pathogenic fungi, and T4 = HU-9 plus pathogenic fungi. The Galaxy-2013 and Pirsbak-2015 varieties are shown on the left and right, respectively. $\mathrm{DW}=$ dry weight, $\mathrm{SL}=$ shoot length, $\mathrm{RL}=$ root length, $\mathrm{LL}=$ leaf length, $\mathrm{FW}=$ fresh weight, $\mathrm{PO}=$ peroxidase, $\mathrm{PPO}=$ polyphenol oxidase, and $\mathrm{PAL}=$ phenylalanine ammonia lyase .

\section{F. moniliforme}

F. moniliforme

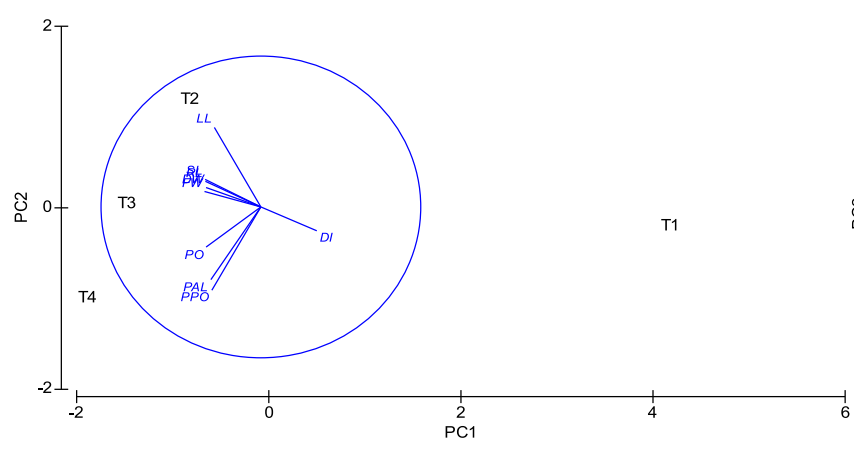

F. oxysporum

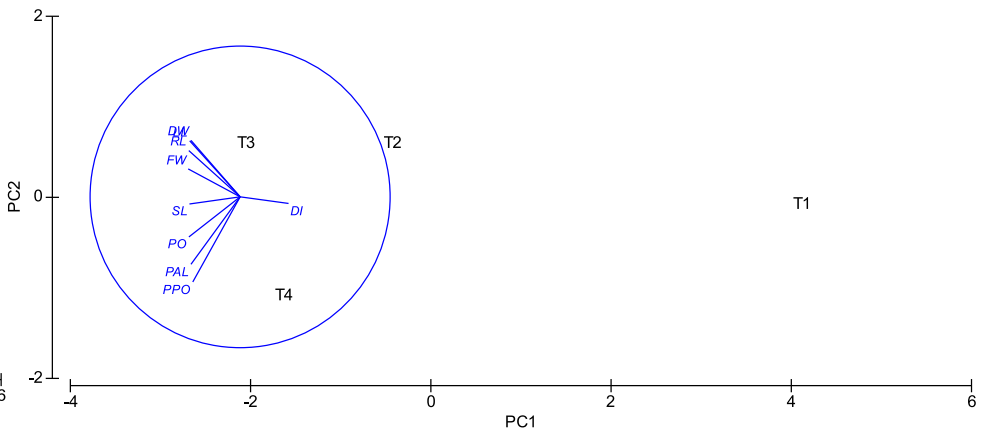

F. oxysporum

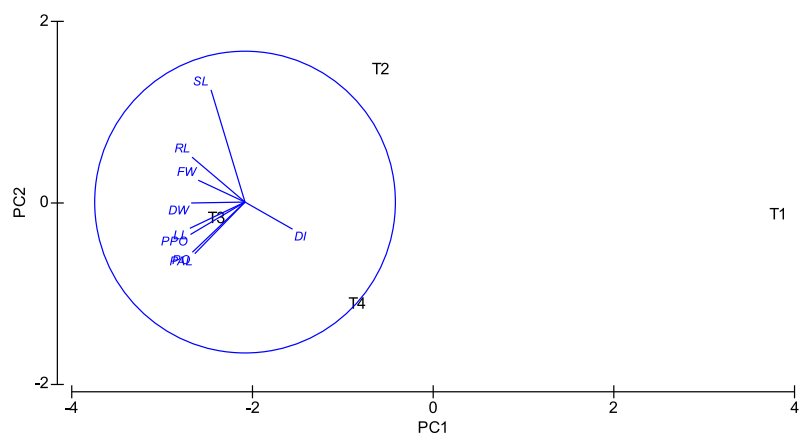

Galaxy- 2013

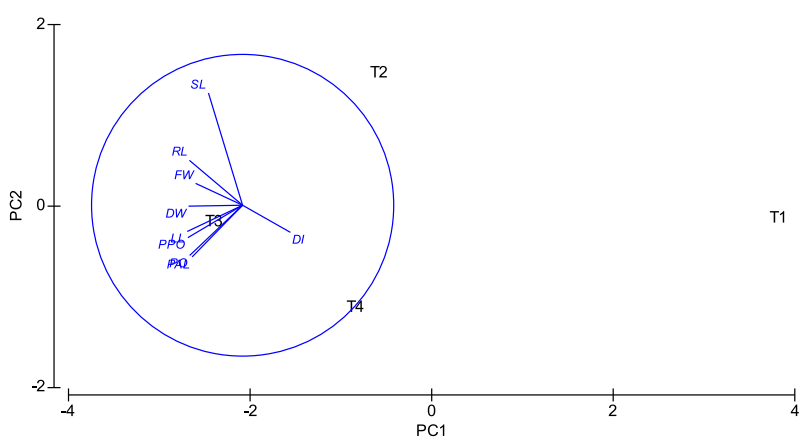

Pirsbak- 2015

Fig. 6. Principal component (PC) analysis between the rhizobacteria and their in planta plant growth-promoting traits (pot experiment). T1 = pathogenic fungi (control), T2 = fungicide plus pathogenic fungi, T3 = HU-8 plus pathogenic fungi, and T4 = HU-9 plus pathogenic fungi. The Galaxy-2013 and Pirsbak-2015 varieties are shown on the left and right, respectively. $\mathrm{LL}=$ leaf length, $\mathrm{SL}=$ shoot length, $\mathrm{RL}=$ root length, $\mathrm{DW}=$ dry weight, $\mathrm{FW}=$ fresh weight, $\mathrm{PO}=$ peroxidase, $\mathrm{PAL}=$ phenylalanine ammonia lyase, and $\mathrm{PPO}=$ polyphenol oxidase . 
2010; Rais et al. 2016; Zhang et al. 2019). Rhizobacteria significantly enhanced wheat plant immunity against Fusarium infection by activating the antioxidative defense system. Biocontrol activity of rhizobacteria against root and crown rot of wheat is well documented across the world (Jaber 2018; Lounaci et al. 2016; Winter et al. 2019). The indigenous antagonistic bacteria inhabiting the arid/semiarid agriculture zone are ideal candidates for the development of biopesticide against root/crown rot because of their adaptability with the host and environment. Their arid/semiarid habitat further strengthens their utilization based on drought-mediated aggravation of root/crown rot disease (Smiley 2019; Wakelin et al. 2018). Induction of antioxidant enzyme activity in wheat against Fusarium spp. depicts the adoption of the induced systemic resistance by the rhizobacteria investigated in this study. The role of these antioxidant enzymes, such as PAL, PPO, and PO, in minimizing the oxidative stress caused by phytopathogens is well reported in numerous studies (Hassan et al. 2015; Rais et al. 2017). We also observed increased activity of antioxidant enzymes in fungicide treatment, which is in accordance with earlier studies. This increased activity may be attributable to the fact that fungicides induce the synthesis of phytoalexins, cell wall lignification, and enzymes involved in the phenolic synthesis (Pantazopoulou and Diallinas 2007; Saladin et al. 2003).

The 16S rRNA gene sequence analysis revealed that the PGPR associated with the monocultured wheat belong to Pseudomonas spp., Ochrobactrum spp., and Acinetobacter spp. The Ochrobactrum spp. depicted high potential to solubilize nutrients, whereas Pseudomonas spp. were found to be potential biocontrol agents. Pseudomonas spp. have been extensively studied for their PGPR activity (Sivasakthi et al. 2014) and are considered as a potential ingredient of biofertilizer and biopesticide. The $16 \mathrm{~S} r R N A$ gene is considered as a valuable tool to identify bacteria at the genus level and has limitations in distinguishing between the closely related species (Lv et al. 2016). However, rpoD is the best housekeeping gene to identify Pseudomonas at the species level (Martens et al. 2008; Mulet et al. 2009, 2010; Savli et al. 2003). P. mediterranea is associated with various cereal crops and its role as a biocontrol agent despite an unusual plant pathogen is well documented. This functional shift from a plant pathogen to a fungal biocontrol agent depicts its diversity in different habitats.

Conclusion. The indigenous Gram-negative antagonistic bacteria inhabiting the arid/semiarid agriculture zone are ideal candidates for the development of biopesticide against root/crown rot because of their adaptability with the host and environment. Their arid/semiarid habitat further strengthens their utilization based on the drought-mediated aggravation of root/crown rot disease. $R p o D$ is the best housekeeping gene for identification of Pseudomonas species. Moreover, a monocropping system of wheat under arid/semiarid agriculture conditions could be an ideal source of beneficial biocontrol agents.

\section{ACKNOWLEDGMENTS}

We thank the National Agriculture Research Centre of Islamabad for providing the wheat seeds.

\section{LITERATURE CITED}

Altschul, S. F., Gish, W., Miller, W., Myers, E. W., and Lipman, D. J. 1990. Basic local alignment search tool. J. Mol. Biol. 215:403-410.

Andrade, O., Campillo, R., Peyrelongue, A., and Barrientos, L. 2011. Soils suppressive against Gaeumannomyces graminis var. tritici identified under wheat crop monoculture in southern Chile. Cienc. Investig. Agrar. 38: 345-356.

Bainard, L., Koch, A., Gordon, A., and Klironomos, J. 2013. Growth response of crops to soil microbial communities from conventional monocropping and tree-based intercropping systems. Plant Soil 363:345-356.

Bajpai, A., and Johri, B. N. 2019. Endophytic Pseudomonads and their metabolites. Pages 33-59 in: Endophytes and Secondary Metabolites. S. Jha, ed. Springer, Cham, Switzerland.
Barnett, S. J., Ballard, R. A., and Franco, C. M. 2019. Field assessment of microbial inoculants to control Rhizoctonia root rot on wheat. Biol. Control 132:152-160.

Bunt, J., and Rovira, A. 1955. Microbiological studies of some subantarctic soils. Eur. J. Soil Sci. 6:119-128.

Cha, J. Y., Han, S., Hong, H. J., Cho, H., Kim, D., Kwon, Y., Kwon, S. K., Crusemann, M., Bok Lee, Y., Kim, J. F., Giaever, G., Nislow, C., Moore, B. S., Thomashow, L. S., Weller, D. M., and Kwak, Y. S. 2016. Microbial and biochemical basis of a Fusarium wilt-suppressive soil. ISME J. 10: $119-129$

Chng, S., Cromey, M. G., Dodd, S. L., Stewart, A., Butler, R. C., and Jaspers, M. V. 2015. Take-all decline in New Zealand wheat soils and the microorganisms associated with the potential mechanisms of disease suppression. Plant Soil 397:239-259.

Cordovez, V., Carrion, V. J., Etalo, D. W., Mumm, R., Zhu, H., van Wezel, G. P., and Raaijmakers, J. M. 2015. Diversity and functions of volatile organic compounds produced by Streptomyces from a disease-suppressive soil. Front. Microbiol. 6:1081.

Coy, R. M., Held, D. W., and Kloepper, J. W. 2019. Rhizobacterial colonization of bermudagrass by Bacillus spp. in a Marvyn loamy sand soil. Appl. Soil Ecol. 141:10-17.

Dasgupta, D., Ghati, A., Sarkar, A., Sengupta, C., and Paul, G. 2015. Application of plant growth promoting rhizobacteria (PGPR) isolated from the rhizosphere of Sesbania bispinosa on the growth of chickpea (Cicer arietinum L.). Int. J. Curr. Microbiol. Appl. Sci. 4:1033-1042.

de Werra, P., Péchy-Tarr, M., Keel, C., and Maurhofer, M. 2009. Role of gluconic acid production in the regulation of biocontrol traits of Pseudomonas fluorescens CHA0. Appl. Environ. Microbiol. 75:4162-4174.

Dinesh, R., Anandaraj, M., Kumar, A., Bini, Y. K., Subila, K. P., and Aravind, R. 2015. Isolation, characterization, and evaluation of multi-trait plant growth promoting rhizobacteria for their growth promoting and disease suppressing effects on ginger. Microbiol. Res. 173:34-43.

Etesami, H., Hosseini, H. M., Alikhani, H. A., and Mohammadi, L. 2014. Bacterial biosynthesis of 1-aminocyclopropane-1-carboxylate (ACC) deaminase and indole-3-acetic acid (IAA) as endophytic preferential selection traits by rice plant seedlings. J. Plant Growth Regul. 33:654-670.

González, J. E., and Marketon, M. M. 2003. Quorum sensing in nitrogenfixing rhizobia. Microbiol. Mol. Biol. Rev. 67:574-592.

Gould, W. D., Hagedorn, C., Bardinelli, T. R., and Zablotowicz, R. M. 1985. New selective media for enumeration and recovery of fluorescent pseudomonads from various habitats. Appl. Environ. Microbiol. 49:28-32.

Han, H., and Lee, K. 2005. Phosphate and potassium solubilizing bacteria effect on mineral uptake, soil availability and growth of eggplant. Res. J. Agric. Biol. Sci. 1:176-180.

Harish, S., Parthasarathy, S., Durgadevi, D., Anandhi, K., and Raguchander, T. 2019. Plant growth-promoting rhizobacteria: Harnessing its potential for sustainable plant disease management. Pages 151-187 in: Plant Growth Promoting Rhizobacteria for Agricultural Sustainability. Springer, Singapore.

Hassan, M. N., Afghan, S., and Hafeez, F. Y. 2010. Suppression of red rot caused by Colletotrichum falcatum on sugarcane plants using plant growthpromoting rhizobacteria. BioControl 55:531-542.

Hassan, M. N., Shah, S. Z.-U.-H., Afghan, S., and Hafeez, F. Y. 2015. Suppression of red rot disease by Bacillus sp. based biopesticide formulated in non-sterilized sugarcane filter cake. BioControl 60:691-702.

Jaber, L. R. 2018. Seed inoculation with endophytic fungal entomopathogens promotes plant growth and reduces crown and root rot (CRR) caused by Fusarium culmorum in wheat. Planta 248:1525-1535.

Khan, M. S., Zaidi, A., and Wani, P. A. 2007. Role of phosphate-solubilizing microorganisms in sustainable agriculture-a review. Agron. Sustain. Dev. 27:29-43.

Kim, O.-S., Cho, Y.-J., Lee, K., Yoon, S.-H., Kim, M., Na, H., Park, S.-C., Jeon, Y. S., Lee, J.-H., and Yi, H. 2012. Introducing EzTaxon-e: A prokaryotic $16 S$ rRNA gene sequence database with phylotypes that represent uncultured species. Int. J. Syst. Evol. Microbiol. 62:716-721.

Kim, Y. C., and Anderson, A. J. 2018. Rhizosphere pseudomonads as probiotics improving plant health. Mol. Plant Pathol. 19:2349-2359.

Kloepper, J. W., Leong, J., Teintze, M., and Schroth, M. N. 1980. Pseudomonas siderophores: A mechanism explaining disease-suppressive soils. Curr. Microbiol. 4:317-320.

Lambrese, Y., Guiñez, M., Calvente, V., Sansone, G., Cerutti, S., Raba, J., and Sanz, M. I. 2018. Production of siderophores by the bacterium Kosakonia radicincitans and its application to control of phytopathogenic fungi. Bioresour. Technol. Rev. 3:82-87.

Larkin, R. P. 2015. Soil health paradigms and implications for disease management. Annu. Rev. Phytopathol. 53:199-221.

Liu, X., Jiang, Q., Hu, X., Zhang, S., Liu, Y., Huang, W., and Ding, W. 2019. Soil microbial carbon metabolism reveals a disease suppression pattern in continuous ginger mono-cropping fields. Appl. Soil Ecol. 144:165-169. 
Lounaci, L., Guemouri-Athmani, S., Boureghda, H., Achouak, W., and Heulin, T. 2016. Suppression of crown and root rot of wheat by the rhizobacterium Paenibacillus polymyxa. Phytopathol. Mediterr. 55: 355-365.

Lukkani, N. J., and Reddy, E. S. 2015. Essential nutrients solubilization ability of fluorescent pseudomonads and their multinutrient management. Int. J. Sci. Res. 4:43-49.

Lv, X.-C., Jia, R.-B., Li, Y., Chen, F., Chen, Z.-C., Liu, B., Chen, S.-J., Rao, P.-F., and Ni, L. 2016. Characterization of the dominant bacterial communities of traditional fermentation starters for Hong Qu glutinous rice wine by means of MALDI-TOF mass spectrometry fingerprinting, 16S rRNA gene sequencing and species-specific PCRs. Food Control 67: 292-302.

Marin-Bruzos, M., and Grayston, S. J. 2019. Biological control of nematodes by plant growth promoting rhizobacteria: Secondary metabolites involved and potential applications. Pages 253-264 in: Secondary Metabolites of Plant Growth Promoting Rhizomicroorganisms. H. Singh, C. Keswani, M. Reddy, E. Sansinenea, and C. García-Estrada, eds. Springer, Singapore.

Martens, M., Dawyndt, P., Coopman, R., Gillis, M., De Vos, P., and Willems, A. 2008. Advantages of multilocus sequence analysis for taxonomic studies: A case study using 10 housekeeping genes in the genus Ensifer (including former Sinorhizobium). Int. J. Syst. Evol. Microbiol. 58:200-214.

Matthews, A., Pierce, S., and Raymond, B. 2019. Rhizobacterial community assembly patterns vary between crop species. Front. Microbiol. 10:581.

Mehmood, A., Liu, G., Wang, X., Meng, G., Wang, C., and Liu, Y. 2019. Fungal quorum-sensing molecules and inhibitors with potential antifungal activity: A review. Molecules 24:1950.

Mekadim, C., Killer, J., Mrázek, J., Bunešová, V., Pechar, R., Hroncová, Z., and Vlková, E. 2018. Evaluation of the $\operatorname{infB}$ and $r p s B$ gene fragments as genetic markers intended for identification and phylogenetic analysis of particular representatives of the order Lactobacillales. Arch. Microbiol. 200:1427-1437.

Mendes, R., Pizzirani-Kleiner, A. A., Araujo, W. L., and Raaijmakers, J. M. 2007. Diversity of cultivated endophytic bacteria from sugarcane: Genetic and biochemical characterization of Burkholderia cepacia complex isolates. Appl. Environ. Microbiol. 73:7259-7267.

Motallebi, P., Alkadri, D., Pisi, A., Nipoti, P., Tonti, S., Niknam, V., Hashemi, M., and Prodi, A. 2015. Pathogenicity and mycotoxin chemotypes of Iranian Fusarium culmorum isolates on durum wheat, and comparisons with Italian and Syrian isolates. Phytopathol. Mediterr. 54:437-445.

Moya-Elizondo, E. A. 2013. Fusarium crown rot disease: Biology, interactions, management and function as a possible sensor of global climate change. Cienc. Investig. Agrar. 40:235-252.

Mulet, M., Bennasar, A., Lalucat, J., and García-Valdés, E. 2009. An rpoDbased PCR procedure for the identification of Pseudomonas species and for their detection in environmental samples. Mol. Cell. Probes 23:140-147.

Mulet, M., Lalucat, J., and García-Valdés, E. 2010. DNA sequence-based analysis of the Pseudomonas species. Environ. Microbiol. 12:1513-1530.

Na, X., Cao, X., Ma, C., Ma, S., Xu, P., Liu, S., Wang, J., Wang, H., Chen, L., and Qiao, Z. 2019. Plant stage, not drought stress, determines the effect of cultivars on bacterial community diversity in the rhizosphere of broomcorn millet (Panicum miliaceum L.). Front. Microbiol. 10:828.

Nautiyal, C. S. 1999. An efficient microbiological growth medium for screening phosphate solubilizing microorganisms. FEMS Microbiol. Lett. 170:265-270.

Pantazopoulou, A., and Diallinas, G. 2007. Fungal nucleobase transporters. FEMS Microbiol. Rev. 31:657-675.

Parmar, P., and Sindhu, S. 2013. Potassium solubilization by rhizosphere bacteria: Influence of nutritional and environmental conditions. J. Microbiol. Res. (Rosemead Calif.) 3:25-31.

Penton, C. R., Gupta, V. V., Tiedje, J. M., Neate, S. M., Ophel-Keller, K., Gillings, M., Harvey, P., Pham, A., and Roget, D. K. 2014. Fungal community structure in disease suppressive soils assessed by 28S LSU gene sequencing. PLoS One 9:e93893.

Poole, G. J., Smiley, R. W., Walker, C., Huggins, D., Rupp, R., and Abatzoglou, J. 2013. Effect of climate on the distribution of Fusarium spp. causing crownrot of wheat in the Pacific Northwest of the United States. Phytopathology 103:1130-1140.

Raaijmakers, J. M., and Mazzola, M. 2016. Soil immune responses. Science 352:1392-1393.

Rais, A., Jabeen, Z., Shair, F., Hafeez, F. Y., and Hassan, M. N. 2017. Bacillus spp., a bio-control agent enhances the activity of antioxidant defense enzymes in rice against Pyricularia oryzae. PLoS One 12:e0187412.

Rais, A., Shakeel, M., Hafeez, F. Y., and Hassan, M. N. 2016. Plant growth promoting rhizobacteria suppress blast disease caused by Pyricularia oryzae and increase grain yield of rice. BioControl 61:769-780.

Rais, A., Shakeel, M., Malik, K., Hafeez, F. Y., Yasmin, H., Mumtaz, S., and Hassan, M. N. 2018. Antagonistic Bacillus spp. reduce blast incidence on rice and increase grain yield under field conditions. Microbiol. Res. 208: 54-62.

Ramawat, K. G., and Goyal, S. 2019. Co-evolution of secondary metabolites during biological competition for survival and advantage: An overview. Pages 1-15 in: Co-Evolution of Secondary Metabolites. Reference Series in Phytochemistry. J. M. Merillon and K. Ramawat, eds. Springer, Cham, Switzerland.

Ramzani, P. M. A., Khalid, M., Naveed, M., Ahmad, R., and Shahid, M. 2016. Iron biofortification of wheat grains through integrated use of organic and chemical fertilizers in $\mathrm{pH}$ affected calcareous soil. Plant Physiol. Biochem. 104:284-293.

Rashid, M., Khalil, S., Ayub, N., Alam, S., and Latif, F. 2004. Organic acids production and phosphate solubilization by phosphate solubilizing microorganisms (PSM) under in vitro conditions. Pak. J. Biol. Sci. 7:187-196.

Raza, M., Farooq, M., Muhammad, S., and Aslam, U. 2015. Efficacy of different commercially available weedicides on wheat Triticum aestivum in Rawalpindi Pakistan. Int. J. Agron. Agric. Res. 7:205-209.

Saladin, G., Magné, C., and Clément, C. 2003. Effects of fludioxonil and pyrimethanil, two fungicides used against Botrytis cinerea, on carbohydrate physiology in Vitis vinifera L. Pest Manag. Sci. 59:1083-1092.

Savli, H., Karadenizli, A., Kolayli, F., Gundes, S., Ozbek, U., and Vahaboglu, H. 2003. Expression stability of six housekeeping genes: A proposal for resistance gene quantification studies of Pseudomonas aeruginosa by realtime quantitative RT-PCR. J. Med. Microbiol. 52:403-408.

Schlatter, D., Kinkel, L., Thomashow, L., Weller, D., and Paulitz, T. 2017. Disease suppressive soils: New insights from the soil microbiome. Phytopathology 107:1284-1297.

Schlemper, T. R., van Veen, J. A., and Kuramae, E. E. 2018. Co-variation of bacterial and fungal communities in different sorghum cultivars and growth stages is soil dependent. Microb. Ecol. 76:205-214.

Schroth, M. N., and Hancock, J. G. 1982. Disease-suppressive soil and rootcolonizing bacteria. Science 216:1376-1381.

Schwyn, B., and Neilands, J. 1987. Universal chemical assay for the detection and determination of siderophores. Anal. Biochem. 160:47-56.

Shakeel, M., Rais, A., Hassan, M. N., and Hafeez, F. Y. 2015. Root associated Bacillus sp. improves growth, yield and zinc translocation for basmati rice (Oryza sativa) varieties. Front. Microbiol. 6:1286.

Sharma, A., and Johri, B. 2003. Growth promoting influence of siderophoreproducing Pseudomonas strains GRP3A and PRS 9 in maize (Zea mays L.) under iron limiting conditions. Microbiol. Res. 158:243-248.

Shen, Z., Ruan, Y., Xue, C., Zhong, S., Li, R., and Shen, Q. 2015. Soils naturally suppressive to banana Fusarium wilt disease harbor unique bacterial communities. Plant Soil 393:21-33.

Shikur Gebremariam, E. S., Sharma-Poudyal, D., Paulitz, T. C., Erginbas-Orakci, G., Karakaya, A., and Dababat, A. A. 2018. Identity and pathogenicity of Fusarium species associated with crown rot on wheat (Triticum spp.) in Turkey. Eur. J. Plant Pathol. 150:387-399.

Siegel-Hertz, K., Edel-Hermann, V., Chapelle, E., Terrat, S., Raaijmakers, J. M., and Steinberg, C. 2018. Comparative microbiome analysis of a Fusarium wilt suppressive soil and a Fusarium wilt conducive soil from the Chateaurenard region. Front. Microbiol. 9:568.

Sivasakthi, S., Usharani, G., and Saranraj, P. 2014. Biocontrol potentiality of plant growth promoting bacteria (PGPR)-Pseudomonas fluorescens and Bacillus subtilis: A review. Afr. J. Agric. Res. 9:1265-1277.

Smiley, R. 2019. Fusarium crown rot white head symptom as influenced by wheat crop management and sampling date. Plant Dis. 103:2612-2623.

Tan, Z.-Y., Xu, X.-D., Wang, E.-T., Gao, J.-L., Martinez-Romero, E., and Chen, W.-X. 1997. Phylogenetic and genetic relationships of Mesorhizobium tianshanense and related rhizobia. Int. J. Syst. Evol. Microbiol. 47:874-879.

Thomashow, L. S., Kwak, Y. S., and Weller, D. M. 2019. Root-associated microbes in sustainable agriculture: Models, metabolites and mechanisms. Pest Manag. Sci. 75:2360-2367.

Truyens, S., Weyens, N., Cuypers, A., and Vangronsveld, J. 2015. Bacterial seed endophytes: Genera, vertical transmission and interaction with plants. Environ. Microbiol. Rep. 7:40-50.

Upadhyay, N., Singh, V. K., Dwivedy, A. K., Das, S., Chaudhari, A. K., and Dubey, N. K. 2018. Cistus ladanifer L. essential oil as a plant based preservative against molds infesting oil seeds, aflatoxin B1 secretion, oxidative deterioration and methylglyoxal biosynthesis. LWT 92:395-403.

van Bruggen, A., and Semenov, A. 2000. In search of biological indicators for soil health and disease suppression. Appl. Soil Ecol. 15:13-24.

Van der Ent, S., and Pieterse, C. M. 2012. Ethylene: Multi-tasker in plantattacker interactions. Annu. Plant Rev. 44:343-377.

van der Voort, M., Kempenaar, M., Driel, M., Raaijmakers, J. M., and Mendes, R. 2016. Impact of soil heat on reassembly of bacterial communities in the rhizosphere microbiome and plant disease suppression. Ecol. Lett. 19: $375-382$. 
Volova, T. G., Prudnikova, S. V., and Zhila, N. O. 2018. Fungicidal activity of slow-release $\mathrm{P}(3 \mathrm{HB}) / \mathrm{TEB}$ formulations in wheat plant communities infected by Fusarium moniliforme. Environ. Sci. Pollut. R. 25:552-561.

Wakelin, S. A., Gomez-Gallego, M., Jones, E., Smaill, S., Lear, G., and Lambie, S. 2018. Climate change induced drought impacts on plant diseases in New Zealand. Australas. Plant Pathol. 47:101-114.

Wildermuth, G., Thomas, G., Radford, B., McNamara, R., and Kelly, A. 1997. Crown rot and common root rot in wheat grown under different tillage and stubble treatments in southern Queensland, Australia. Soil Tillage Res. 44: 211-224.

Winter, M., Samuels, P. L., Otto-Hanson, L. K., Dill-Macky, R., and Kinkel, L. L. 2019. Biological control of Fusarium crown and root rot of wheat by Streptomyces isolates-it's complicated. Phytobiomes J. 3:52-60.

Xiong, W., Li, R., Ren, Y., Liu, C., Zhao, Q., Wu, H., Jousset, A., and Shen, Q. 2017. Distinct roles for soil fungal and bacterial communities associated with the suppression of vanilla Fusarium wilt disease. Soil Biol. Biochem. 107:198-207.

Yin, C., Hulbert, S. H., Schroeder, K. L., Mavrodi, O., Mavrodi, D., Dhingra, A., Schillinger, W. F., and Paulitz, T. C. 2013. Role of bacterial communities in the natural suppression of Rhizoctonia solani bare patch disease of wheat (Triticum aestivum L.). Appl. Environ. Microbiol. 79:7428-7438.

Zhang, C., and Kong, F. 2014. Isolation and identification of potassiumsolubilizing bacteria from tobacco rhizospheric soil and their effect on tobacco plants. Appl. Soil Ecol. 82:18-25.

Zhang, Y., Gao, X., Shen, Z., Zhu, C., Jiao, Z., Li, R., and Shen, Q. 2019. Precolonization of PGPR triggers rhizosphere microbiota succession associated with crop yield enhancement. Plant Soil 439:553-567.

Zhao, Q., Xiong, W., Xing, Y., Sun, Y., Lin, X., and Dong, Y. 2018. Long-term coffee monoculture alters soil chemical properties and microbial communities. Sci. Rep. 8:6116.

Zhou, D., Huang, X.-F., Chaparro, J. M., Badri, D. V., Manter, D. K., Vivanco, J. M., and Guo, J. 2015. Root and bacterial secretions regulate the interaction between plants and PGPR leading to distinct plant growth promotion effects. Plant Soil 401:259-272.

Zia, M. A., Yasmin, H., Shair, F., Jabeen, Z., Mumtaz, S., Hayat, Z., Afghan, S., Hafeez, F. Y., and Hassan, M. N. 2019. Glucanolytic rhizobacteria produce antifungal metabolites and elicit ROS Scavenging System in Sugarcane. Sugar Tech. 21:244-255. 